\title{
The Difference in Academic Performance of Private and Public Elementary School Graduates
}

DOI: https://doi.org/10.47175/rielsj.v1i3.135

\author{
1,2,3 Feu-NRMF, General \\ Education Department, \\ Quezon City Philipppines, \\ Arellano University Jose abad \\ Santos Campus Pasay City, \\ Philippines, FRV National High \\ School, Bulacan City, \\ Philippines
}

| Hernando L. Bernal Jr ${ }^{1, *} \mid$ Renz Chester Gumaru² Sammy T. Oleo $^{3}$ |

*bhambernal@gmail.com

\begin{abstract}
The study is about the difference of Private and Public elementary school graduates. The type of elementary school in which a person graduated from is a factor that can affect their future academic performance; it can also be a factor for schools in choosing which student to accept in their community. It also test and shows the quality of the teachers in both types of school.

The researchers conducted the study to verify if there was an actual difference on the academic performance of the graduates on each of the two types of elementary school. The researchers believe that the results of this study will be beneficial to a lot of people especially students and teachers. The researchers collected, compared, and interpret the grades of students of both public school graduates and private school graduates. The gathered data are test using different statistical tools and formulas. This study found out that there is a significant difference between public school graduates and private school graduates in terms of academic performance.
\end{abstract}

KEYWORDS

Academic performance; public school; private school; students; teachers

\section{INTRODUCTION}

In our generation, the Private and Public schools have a huge difference. ThePublic and Private schools each have their own positive and negative stereotypes. A fewof these stereotypes are: Public students are mostly bullies, cigarette smokers, and even drug addicts. Some say that Private school students are arrogant and lazy. The researchers thought that if these kinds of stereotypes were to be abolished, then our community can have equal perceptions with each other.

We are all aware that most students coming from public elementary schools have financial problems in their family. We are also aware that problems can be used by a person as a motivation to study harder. Our group realized that students coming from public elementary schools often overwork those coming from private schools.

Private elementary schools also have an edge against Public elementary schools. Private elementary schools have a small and refined community. For this reason, teachers are able to focus their attention on individual students. Private schools can do expulsion; this is very rare in public elementary schools. Public schools consider that education is a right and not a privilege. Consequently, private elementary school students have a great advantage against public elementary school students.

The researchers had observed that both schools have each unique advantage against each other. One of which is that private elementary schools have better facilities, on the other hand Public elementary schools have better school teachers and personnel. 
The researchers conducted this study because they want to prove that not all students coming from public elementary schools are stupid, and not all students from private elementary schools are arrogant. The researchers wanted to abolish negative stereotypes which can affect the students socially.

According to John Cloud (2011) his study shows that sending your kid to private school is still a better way to ensure that he/she will get into college. http://content.time.com/time/nation/article/0,8599,1670063,00.html

Clarence Durham (2010) suggested that "there are no table differences in what private school offer from the public school."

Zebienski (2012), found out that when student background, mainly ES, was taken into account, students attending public schools actually outperform students at private schools

According to major study from the National Center for Education Statistics (2013) public school teachers tend to be more qualified than their private school counter-parts in terms of education and experience. For example, they're more likely to have a master's degree, and to have logged more hours pursuing in-service study - learning, for example, how to use computers in the classroom. The report also indicates that on average, public school teachers earn higher salaries than those in private schools do. They also stated that private schools tend to be half as large as public schools. Many experts feel that children are less likely to get lost in the shuffle if they attend a smaller school, which naturally nurtures a sense of community and belonging. In addition, the teacher-student ratios in private schools tend to be more favorable.

From the research entitled "All Private and Public Elementary schools are equal" Taylor(2013) expounded that "private school are organized around principles other than academic outcomes, such as religious beliefs, safety or discipline; in some cases, academic achievement was a relatively low priority"

According to an article in the internet entitled "Public School vs. Private Schools": new studies study says that there is no difference. Students in public schools perform on average, just as well as those studying in private schools.

The results of a new study show that private school education may be no better than public school education. Keep reading to learn more about this study and to learn how to make the right choice between private and public school education for your child. (Kate Barrington, New Study Confirms That Private Schools Are No Better Than Public Schools, March 20, 2019)

Private high school students score significantly higher than public high school students on reading, mathematics, and science assessments at age 15, and have higher levels of educational attainment by age 23. Two factors consistently account for these differences. Students who attended private high schools were more likely to have socio-economic characteristics positively associated with academic success and to have school peers with university-educated parents. Province of school attendance accounted for a substantial portion of the differences in academic outcomes measured in high school (i.e., test scores and high school graduation rates), but generally not at the postsecondary level. School resources and practices accounted for little of the differences in academic outcomes. (Marc Frenette, Academic Outcomes of Public and Private High School Students: What Lies Behind the Differences?, 2015)

Researchers and activists have long debated the different effects of school governance on student achievement. Some studies have purportedly found that students in private schools significantly outperform their public school counterparts. In fact, much of the argument for market reforms in education-including vouchers and charter schools-revolves around the assumption that private governance results in higher student achievement at 
similar (or lower) cost when compared to public governance. (Lubienski, S., \&Lubienski, C. , Public and Private Schools’ Performance: Does Governance Matter? , 2005).

Good performances in private schools have notonly attracted many parents but also left the public wondering what secret could be behind their success. Despite government investing heavily in public schools, notmuch in terms of performance is yet realized. Most public schools,especially in urban areas, are well staffed. Teachers in public schools are better paid compared to those in private.(Samuel K. Rong, a Comparison of Academic Performance between Public and Private Secondary Schools in Wareng District, Kenya, 2017).

Theoretical and Conceptual Framework

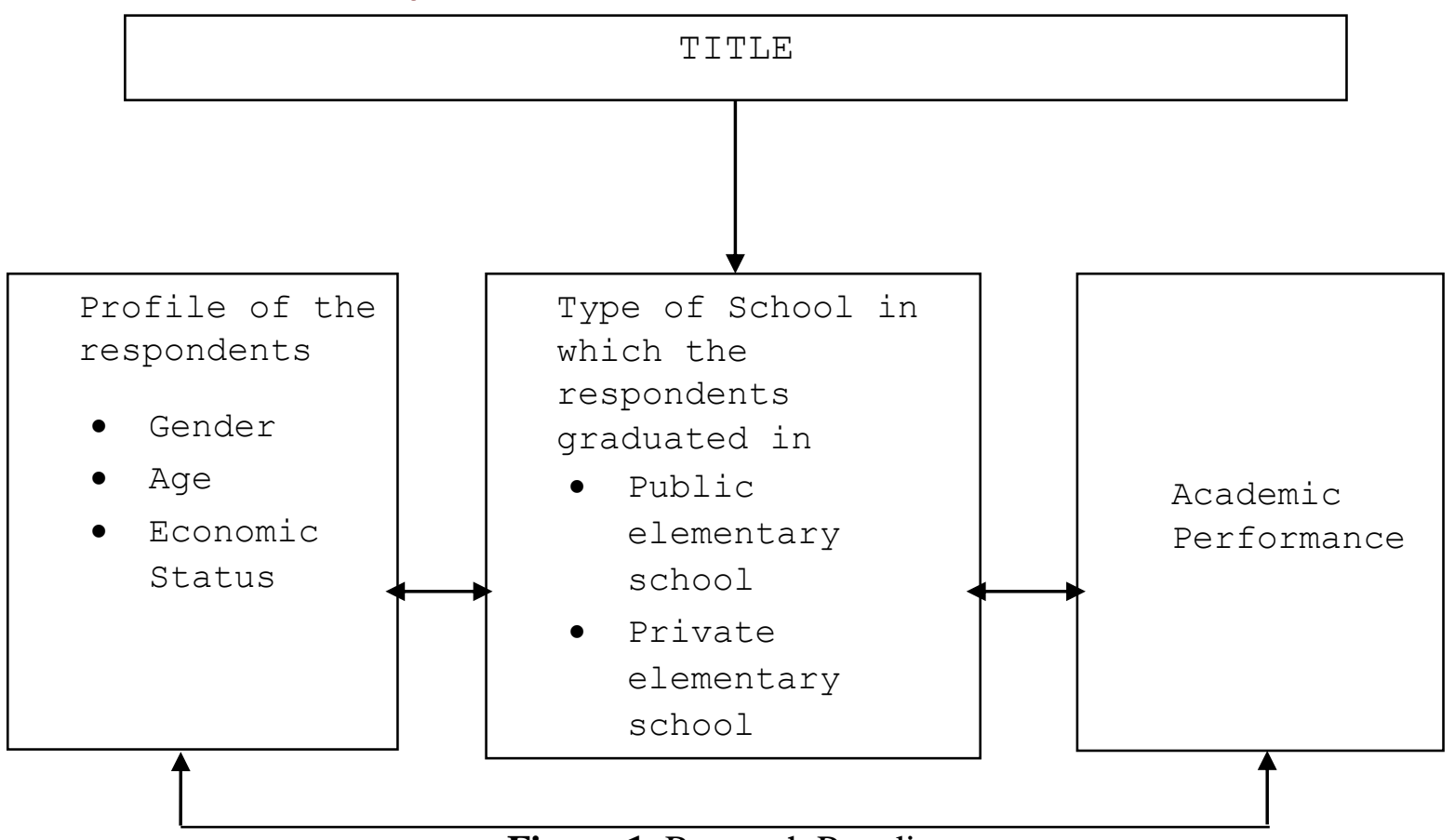

Figure 1. Research Paradigm

The conceptual framework above illustrates the data to be used by the researchers in conducting the research. The data consists of the Profile variables of the respondents; namely, the gender, age, and economic status; the type of school in which they graduated, and their academic performance in the $1^{\text {st }}$ and $2^{\text {nd }}$ quarter.

This research was aimed to know if there is a difference in academic performance between the Public elementary school graduates and Private elementary school graduates

1. What is the profile of the grade 7 students of a sampled schools according to:

a. Gender

b. Economic status

2. What is the type of elementary school in which the respondents graduated?

a. Public

b. Private

3. What is the academic performance of the grade 7 students of a sampled school in the following grading period:

a. First Grading Period

b. Second Grading Period

4. Is there a significant difference in the academic performance of the public and private elementary school graduates? 


\section{Hypotheses}

The researchers found the hypothesis helpful as a base for the determining assumptions and for the explanation about the data to be gathered. We, the researchers, will be aware about our temporary answers, we will know if it is correct or wrong. There is no significant difference between the academic performance of private elementary school graduates and public elementary school graduates.

\section{RESEARCH METHODS}

The research method used in this study is the "descriptive method of research". Descriptive research aims to accurately and systematically describe a population, situation or phenomenon.(Mccombes. 2019), the Descriptive method may be defined as a purposive process of gathering, analyzing, classifying and tabulating data. It usually uses survey questionnaires to gather data.

The researches uses purposeve sampling because it revolves around the respondents because they are the source of the required data and the necessary information. Purposive sampling, also known as judgmental, selective, or subjective sampling, is a form of nonprobability sampling in which researchers rely on their own judgment when choosing members of the population to participate in their study.(Foley. 2018). Consequently, the respondents are very important in each research study. Each study needs a particular set of respondents for them to make a conclusion about the problem that they are discussing. In this study, there are 133 chosen respondents, which are the grade 7 students of a sampled school. This is because, objectively, these students are fresh from their elementary years.

\section{Research Instruments}

Research Instrument refers to the tool used to gather data that are necessary. Obviously, data is very important in a study due to the fact that it provides the basis for observations. In order to obtain the data needed, the researchers used the questionnaire as the research instrument. The questionnaire intends to gather personal information or demographic background of the chosen respondents. This involves the name, year level, monthly income, gender, and kind of elementary school they graduated in. The researchers also collected the grades of the respondents in the $1^{\text {st }}$ and $2^{\text {nd }}$ grading quarters.

\section{School Records}

To determine the verbal interpretation of the academic performance of the respondents, the researchers had noted a letter that asked the Guidance Counselor to get the respondent's record. The records of the respondents were copied and were checked carefully by the researchers in order to avoid inaccurate information. The grades were classified as:

Proficient: $90 \%$ and above

Advanced: $85 \%$ - 89\%

Approaching Proficient: $80 \%-84 \%$

Developing: $75 \%$ - 79\%

Beginning: 74 and below

\section{Statistical Tools/Treatment of Data}

This part presents the different formulas/equations used in computations for the interpretation of the different data gathered and for the correlation of the different variables included in the research study. 


\section{Percentage Distribution}

This tool is used to express the percentage of the total frequency that is equated to 100 . This was needed to gather the percentageof the frequency of responses for a specific problem

Formula:

$$
\%=\frac{f}{n} x 100
$$

Where:

$\mathrm{f}$ - Frequency of respondents

$\mathrm{n}$ - Number of the total respondents

\section{Mean}

The mean was used to measure the central tendency of the academic performance of the grade 7 students. The mean is computed be adding all the scores and dividing by the number of scores.

$$
\bar{x}=\frac{\sum x_{i}}{n}
$$

Where:

$\sum x_{i}=$ the sum of all the scores

$n=$ number of scores

\section{Standard Deviation}

It tells how tightly all the various examples are clustered around the mean in a set of data.

$$
s=\sqrt{\frac{\sum(x-\bar{x})^{2}}{(n)}}
$$

Where

$\mathrm{x}=$ ungrouped data

$\bar{x}=$ mean of the data

$\mathrm{s}=$ Standard Deviation

$\mathrm{n}=$ number of measurements

\section{T-Test}

It is used to calculate the significant difference existing among the groups only. It is used by the researchers to calculate the difference between these factors comparing with only two variables.

$$
t=\frac{\left|\bar{x}_{1}-\bar{x}_{2}\right|}{\sqrt{\frac{\left(s_{1}\right)^{2}}{n_{1}}+\frac{\left(s_{2}\right)^{2}}{n_{2}}}}
$$

\section{RESULTS AND DISCUSSION}

\section{Profile of the Respondents}

The researchers used the grade 7 students as the respondents of the study. There are 133 students in the grade 7 year level and the researchers utilized all of them in the study. 
Table 1. Distribution of Respondents According to Gender

\begin{tabular}{ccc}
\hline Gender & Freq. & \% \\
\hline Male & 67 & $50.38 \%$ \\
Female & 66 & $49.62 \%$ \\
\hline Total & 133 & $100 \%$ \\
\hline
\end{tabular}

Table 1. shows the distribution of the respondents when grouped according to gender. The respondents are made up of 67 or $50.38 \%$ male and 66 or $49.62 \%$ female students with the total of 133 respondents.

This table shows that the Male respondents exceed the Female respondents by 1 only, which implies that there is no large difference between the genders of the respondents.

Table 2. Distribution of Respondents According to Economic Status

\begin{tabular}{ccc}
\hline ES & Freq. & \% \\
\hline Below 10,000 (P) & 32 & $24.06 \%$ \\
$10,000-20,000(\mathrm{~A})$ & 35 & $26.32 \%$ \\
$21,000-30,000(\mathrm{AA})$ & 41 & $30.83 \%$ \\
Above 30,000 (R) & 25 & $18.79 \%$ \\
\hline Total & 133 & $100 \%$ \\
\hline
\end{tabular}

Table 2 presents the distribution of the respondents when grouped according to the Economic Status of their family. The table shows that there are 41respondents, or $30.83 \%$ of the total respondentsthat belongs to the family which has 21,000 - 30,000 monthly income; 35 respondents or $26.32 \%$ of the total respondents belongs to the $10,000-20,000$ family monthly income; 32respondents or $24.06 \%$ of the total respondents belongs to the below 10,000 family monthly income, and lastly there are 25respondents or $18.79 \%$ of the total respondentswhich belongs toabove 30,000family monthly income.

There are 4 particular ratings according which the researchers used to give a verbal interpretation to the family monthly income: below 10,000 is considered as poor family income, $11,000-20,000$ is considered as average family income, $21,000-30,000$ is considered as above average family income and above 30,000 which is considered as rich family income.

\section{Type of School Where the Respondents Have Graduated in}

The researchers used a survey questionnaire to collect data about the past school information of the respondents. In table 2, the researchers present the distribution of the respondents according to the school they graduated in.

Table 3. Type of School in Which the Respondents Graduated in

\begin{tabular}{ccc}
\hline Type of School & F & \% \\
\hline Private & 60 & $45.11 \%$ \\
Public & 73 & $54.89 \%$ \\
\hline Total & 133 & $100 \%$ \\
\hline
\end{tabular}

Table 3 shows that 73 respondents or $54.89 \%$ of the total respondents graduated in a Public elementary school and 60 respondents or $45.11 \%$ of the totalrespondents graduated in a Private elementary school. 
This table implies that there is no great difference in the number of respondents that graduated in each type of school. Hence, the researchers did not bother to equal the number of data to be used in each type of school.

\section{Academic Performance of the Respondents During the $1^{\text {st }}$ And $2^{\text {nd }}$ Quarter of Sy 2013-} 2014

The table in the next 2 pages will present the grades of the respondents during the first and second grading period of S.Y. 2013-2014. With these tables we can observe if there is a change between the academic performances of the respondents.

Table 4. The Academic Performance of the Respondents during The $1^{\text {st }}$ Quarter of Sy 2013-2014

\begin{tabular}{ccc}
\hline Academic Performance & F & $\%$ \\
\hline 90\% and above(Proficient) & 11 & $8.27 \%$ \\
$85 \%$ - 89\%(Advanced) & 43 & $32.33 \%$ \\
$80 \%-84 \%$ (Approaching Proficient) & 65 & $48.87 \%$ \\
$75 \%$ - 79\%(Developing) & 14 & $10.53 \%$ \\
74 and below(Beginning) & 0 & $0 \%$ \\
\hline Total & 133 & $100 \%$ \\
\hline
\end{tabular}

Table 4 shows the level of academic performance of the respondents during the $1^{\text {st }}$ grading quarter of SY 2013-2014. The mean of the grades of the respondents during the $1^{\text {st }}$ quarter is 83.84 with a verbal interpretation of Approaching Proficient.This table implies that most of the respondents have a grade of $80 \%-84 \%$ which makes up of $48.87 \%$ of the total respondents.

Table 5. The Academic Performance of the Respondents during the $2^{\text {nd }}$ Quarter of Sy 2013-2014

\begin{tabular}{ccc}
\hline Academic Performance & F & \% \\
\hline $90 \%$ and above(Proficient) & 14 & $10.53 \%$ \\
$85 \%-89 \%$ (Advanced) & 42 & $31.58 \%$ \\
$80 \%-84 \%$ (Approaching Proficient) & 64 & $48.12 \%$ \\
$75 \%-79 \%$ (Developing) & 13 & $9.77 \%$ \\
74 and below(Beginning) & 0 & $0 \%$ \\
\hline Total & 133 & $100 \%$ \\
\hline
\end{tabular}

Table 5 shows the level of academic performance of the respondents during the $2^{\text {nd }}$ grading quarter of SY 2013-2014. The mean of the grades of the respondents during the $2^{\text {nd }}$ quarter is 84.22 with a verbal interpretation of Approaching Proficient. This table implies that most of the respondents have a grade of $80 \%$ - $84 \%$ which makes up of $48.12 \%$ of the total respondents. It also implies that there is a very small change in the average academic performance of the respondents.

\section{The Difference in the Academic Perfromance of the Privte And Public Elementary Schoool Graduates}

This part will present how the Null Hypothesis was tested by the researchers, to determine whether there the variables have a significant difference. 
Table 6. The Difference in the Academic Performance of the Private and Public Elementary School Graduates

\begin{tabular}{|c|c|c|}
\hline \multirow{2}{*}{$\begin{array}{l}\text { Factors Compared } \\
\text { in the Study }\end{array}$} & \multicolumn{2}{|c|}{ VALUES } \\
\hline & Mean & STDEV \\
\hline $\begin{array}{c}\text { Academic Performance of Private elementary } \\
\text { school graduates }\end{array}$ & 84.90 & 4.17 \\
\hline $\begin{array}{c}\text { Academic Performance of Public elementary } \\
\text { school graduates }\end{array}$ & 83.31 & 3.21 \\
\hline \multicolumn{3}{|c|}{ T-Test } \\
\hline $\mathrm{t}($ Computed $)$ & & \\
\hline $\mathrm{t}($ Critical) & & \\
\hline
\end{tabular}

Table 6 shows the difference in the academic performance of the Private and Public elementary school graduates. The computed $t$ has a value of 2.42 , while the $t$-critical is 1.98. The computed $\mathrm{t}$ is greater than the $\mathrm{t}$-critical; therefore the Null Hypothesis is REJECTED, which implies that there is a significant difference in the academic performance of the Private and Public elementary school graduates. The result on the table simply implies that the Private elementary school graduates perform better that the Public elementary school graduates.

\section{CONCLUSION}

After the analysis and interpretation of the findings, the researchers came up with the following conclusion:

1. There is a significant difference between the academic performance of privateelementary school graduates and public elementary school graduates.

2. Private elementary school graduates perform better than public elementary graduates.

The researchers recommend future researchers to consider and identify other factors affecting the academic performance of students. Additionally, it is recommended also to identify the academic performance of high school students when they are in elementary.

\section{REFERENCES}

Barrington, K. (2019).“New Study Confirms That Private Schools Are No Better Than Public Schools. https://www.publicschoolreview.com/blog/new-study-confirms-that-private-schoolsare-no-better-than-public-schools

Chen, G. (2019). "Public Schools Vs Private Schools" https://www.publicschoolreview.com/blog /public-school-vs-private-school.

Cloud, J. (2011). “Are private Schools really “content.time.com/time/nation/article 10,8599,1670063,00.html

Frenette, M. (2015). "Academic Outcomes of Public and Private High School Students: What Lies Behind the Differences?". https://www150.statcan.gc.ca/n1/pub/11f0019m/11f0019m2015367eng.htm

Lubienski, S., \& Lubienski, C. (2005). "Public and Private Schools' Performance: Does Governance Matter?". http://www.ascd.org/publications/researchbrief/v3n12/toc.aspx

Mccombes,S. (2019). https://www.scribbr.com/methodology/descriptive-research/

National Center for Education Statistics. (2013)

Rong, S. (2017). "Acomparison of Academic Performance between Public and Private Secondary Schools in Wareng District, Kenya". http://www.eajournals.org/wp-content/uploads/AComparison-of-Academic-Performance-between-Public-and-Private-Secondary-Schools-inWareng-District-Kenya.pdf

Taylor. (2013). "All Private and Public Elementary schools are equal" 